\title{
Role, Functions and Types of a Brand as Individualization Means of Products and Organizations
}

\author{
Olga I. Klimenko \\ Anton A. Klimenko
}

Belgorod University of Cooperation, Economics and Law, Sadovaya St., 116-a, Belgorod, Russia, 308023

\section{Doi:10.5901/mjss.2015.v6n2p251}

\section{Abstract}

Today's market economy of Russia based on multisectoral ownership is represented by a variety of business entities of different organizational and legal arrangements and types of economic activity. All of them enter the consumer market as its competent participants for selling products, work performance and service rendering. The multiplicity and diversification of business entities create options for consumers to buy goods or services. Therefore, any business entity should have its individual character to be distinguished or identified by consumers among the objects of the same kind. The possibility to identify some distinctive features of organizations is provided by means of individualization. These means are applied not only to organizations. They are equally important for identifying products (work, services). The theoretical justification of the role and functions of a brand as an individualization means of products and organizations is provided in the article. The authors also present their proper typology of the described phenomenon.

Keywords: Individualization means of an organization, an organization and product brand, functions and types of brands

\section{Introduction}

Commodity consumer markets are characterized by the lack of evidently perceived subjective and merchandising differentiation. In such markets, consumers fail to distinguish competing proposals within a definite commodity category due to a variety of the substitutes produced by different manufacturers in various production sites, even from other kinds of raw materials but satisfying the same requirements of the final customer.

Hence, it is necessary for organizations, willing to differentiate themselves as independent institutions or to single out their commodities (products, works or services) among the objects of the same kind, to use specific marketing instruments for setting their own and their products' certain characteristics and showing them to consumers. These individualization means meet the above-mentioned requirements and include the notion of "a brand" possessing a specific role and functions.

The main objective of this study implies the development of some certain theoretical provisions justifying the significance of a brand as a products and organizations' individualization means permitting identifying a definite organization among competing trade proposals. The study presents the review results of the approaches to typifying brands and suggests the author's typology.

\section{Methodology}

The study of an organization's brand was founded on the fundamental postulates of dialectical and systematical approaches to the perception of processes and phenomena of a contemporary marketing reality as well as factors and tendencies of commodity consumer market development. The study used complex methodological provisions of the applied marketing theory and the notion of "branding", on which the theoretical justification of the role and functions of an organization's brand was based. The mainline methods of the study included logical and morphological analysis, which revealed the essence and contents of individualization means of products and organizations. Certain similar and different features of individualization means of products and organizations in domestic and foreign marketing practices as well as those presented at theoretical concepts of a brand were distinguished by using the method of comparative analysis. While justifying the author's typology, the classification method was effectively applied to typify brands on the criteria of their influence on the added value formation marking out generic, expected, forced and potential ones. The visualization 
of the material was provided by the method of graphic illustration. The method of abstract and logical thinking allowed to generalize the research results and to draw the conclusions.

\section{Results}

\subsection{The concept of individualization means and the problem of their determination.}

The concept of organizations and their products' individualization means comprises designations used to differ manufacturers (sellers) and/or their products from the other ones (5, p.25).

According to the present legislation of the Russian Federation, individualization means are related to the group of intellectual property objects, but it gives no clear legal definition of these means but only approximate ones. In particular, Article 138 of the Civil Code of the Russian Federation presents an open list, which recognizes a trade name, a merchandise mark and a service mark, etc. as individualization means of a legal entity, manufactured products, performed works or rendered services (4). Nevertheless, the notion of "etc." is not defined clearly. Therefore, it might be a commercial designation, a company style or any other element, which makes the organization recognizable and unique.

Among the individualization means, a trade name can be related to as a primary one since a legal entity has to be registered under the definite name and then it gains the right to register its own merchandise mark. Nevertheless, this formal registration leads to improper protection of both a trade name and the rights of its owner. Moreover, an organization's trade name in one subject of the Russian Federation can fully coincide with the other organization's trade name in the other subject of the Russian Federation as until now the Unified State Register of Trade Names has not be established yet.

In practice, it often happens that previously registered organizations under the same trade name continue operating and investing in advertising and promotion of their products and services even not suspecting that their sales are carried out within the illegal usage of intellectual property and its equivalents including the individualization means of legal entities, production, carrying out works and rendering services, and thus are related to as unfair competition with all the consequences that such activities might entail.

From a legal perspective, a service mark is equated with a merchandise mark, so they are both equally legally protected. Nevertheless, the practice shows that there is no difference between service and merchandise marks since the same mark can be registered in the name of a particular owner for either products or services class. Therefore, the formal criteria for assigning to merchandise or service marks should involve the choice of a certain class (index) in the International Trademark Classification system (11, p.35).

Some authors introduce into scientific practice some additional modifications of basic concepts as "a product brand" and "a commercial mark" proposing to regard them as synonyms to the concepts of "a merchandise mark" and "a trademark" (3, p.19).

This identification, in our view, is not sufficiently correct, as a merchandise mark and a trademark are not implicitly equal relating to different aspects of individualization means (respectively, legal and marketing ones). The introduction of additional concepts ("a product brand" and "a merchandise mark") further complicates this already controversial interpretation of an organization's (products') individualization means.

It is also debatable to distinguish the four directions of merchandise marks usage: "a trade name, economic actors' individualization means, a merchandise mark, an appellation of origin of goods" (3, p.20-21).

Firstly, a trade name and an appellation of origin of goods as well as a merchandise mark are related to as independent individualization means brought in compliance with the norms of the effective Russian legislation.

Secondly, "an individualization mean of economic actors" should not be regarded as "the direction of a merchandise mark's usage" since the first notion has wider meaning and "absorbs" the second one.

Additionally, the idea concerning the difference of "an individualization mean of economic actors" from "a trade name", which "... implies that the company actually has its proper name while carrying out economic, commercial, advertising or other activities but within the legal framework it has the other one" $(3, p .20)$ is still arguable.

In case an organization permits some "modifications" of its proper trade name, it will offend the present legal order of economic relations; therefore, the contractual arrangements under a "modified" trade name will be regarded as legally invalid. As a result, it will be impossible to bring an organization to justice even if it fails to perform the obligations arising out from the concluded agreements or breaks their terms. 


\subsection{The legal aspect of positioning of individualization means within intellectual property objects.}

The roundabout way of the legal determination of individualization means leads, in our opinion, to the mix in designation of organizations and their products being often equated, while it is evident that a product name expressed in a merchandise mark and a company name expressed in its trade name are two very different things. Without altering its "corporate name", an organization can possess a number of produced (sold) goods, which consumers unconsciously but necessarily will identify with this organization itself.

From the analysis of the legal provision of individualization means we can draw some significant for our study conclusions.

Firstly, the present legislation fully ignores the recognition criteria of organizations and products' designations; thus, brands that comprise recognition as their basic feature are given no legal protection.

Secondly, the factor of the state registration, determined by the law as the main factor of variation of organizations and their products among themselves, presupposes no consideration of unregistered merchandise marks, trademarks, service marks and other individualization means as above-said distinctive features.

Thirdly, the current list of individualization means brought in Russian legislation is far from being completed and has a "disclosable" character, thus allows uncertainty in both individualization means themselves and the equivalence between them.

Fourthly and finally, the above-mentioned individualization means are regarded by the legislation as a part of intellectual property objects; and this point is considered to be reasonable as the development of individualization means implies intellectual and creative activities. Nevertheless, though this kind of activity is implemented while developing trademarks and brands, this fact is ignored by the legislation.

Figure 1 illustrates the relationship between intellectual property objects in the sequence as defined by the present legislation of the Russian Federation.

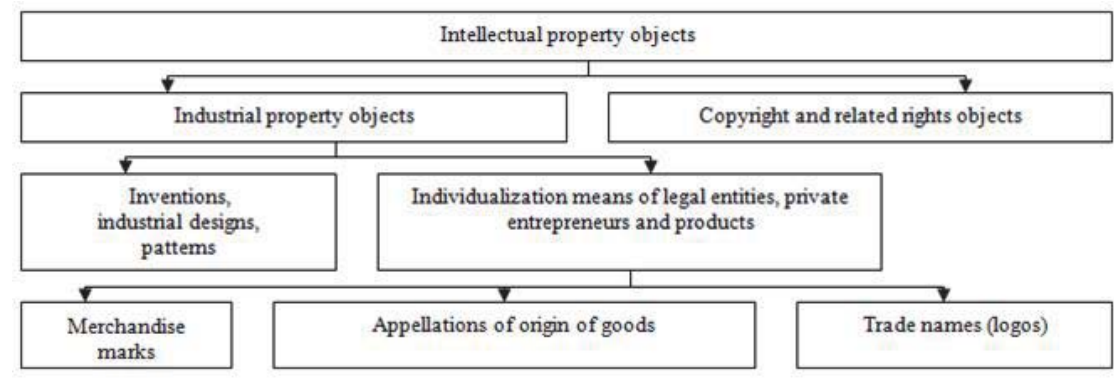

Figure 1. The relationship between intellectual property objects defined by the present legislation of the Russian Federation

The scheme shows clearly a lack of "a brand" and "a trademark" notions. Consequently, as it was mentioned above, their implementation in economic activity is related to as legally invalid. Nevertheless, the current practice uses them widely, and the lack of their legal definitions is not a barrier to involve brands and trademarks in economic environment.

Therefore, we believe that it is necessary to establish the levels of interrelation and interdependence between individualization means, a brand and a trademark that allow to set a position of "a brand" among these means. However, initially, the following points are worth to be noting.

As it is widely known, the foreign practice implements only two basic notions to refer to organizations and their products' individualization means: "a trademark" and "a brand" $(1,10,20,21,22,24$, etc.). The interrelation between them is explained in a simple way: a brand is an easily recognizable, popular, well-known and top-ranked trademark.

For instance, K. Menar and I. Valtzeskini write, "We consider the notions of "a brand" and "a trademark" as synonyms". In our opinion, there is no difference between the notions of "a brand" and "a trademark" in terms of the English language. The only distinction is that "a trademark" is a legal term applied to registered entities. However, the majority of brands are among them" (12, p.77).

Nonetheless, there is a notion of "a trademark" in English language literature, but its definition bears somewhat altered meaning. This interpretation not only identifies a product or a service with the assistance of a certain set of properties and characteristics, but also accumulates all feelings and emotions that customers could experience $(2,26)$.

In Russian practice, the notion of "a trademark" is translated into Russian in two ways depending on the context: 
- as "a merchandise mark" if there is a need to highlight its legal protection;

- as "a trademark" to underline not legal but economic and marketing usage of this term.

However, "a trademark" is a wider notion than "a merchandise mark", at least, from perspectives of the three aspects: the degree of consumer's attitude to a merchandise mark, the degree of its legal protection and the evaluation of the state antimonopoly institutions' activity.

It entails that not every trademark as well as not every merchandise mark can be viewed as "a brand". In addition, not every brand can be regarded as "a trademark" (due to the obligation to be registered) since a popular and recognizable trademark possessing a brand should obtain registration in Rospatent (the Federal Service for Intellectual Property).

\subsection{The brand essence; the place and the role of the brand in the individualization of an organization and a product.}

In regards to the brand essence, our position is that a trademark is considered as a part of a brand evolving from a merchandise mark. Branded products (i.e. products identified by a particular trademark) not only have a particular name and packing, but also give rise to positive emotions, inclination, trust, and commitment.

The following quote can confirm our point of view: "The concept of the brand is broader than the brand name, as it also includes a product or a service with all their characteristics; a set of characteristics, expectations and associations perceived by a customer and attributed to a product (product image), as well as a promise of any benefits given by a brand creator to consumers, i.e., the values attributed to a brand by its creator" (16, p. 57).

From this perspective the brand can be considered as established relationships between a manufacturer and a consumer, which guarantee the latter that products with a specific name and appearance will always confirm the promise (to meet specific needs, to ensure products and services meet quality requirements, and so on) they give.

According to some researchers (for example, O.A Tretiak) a brand is "a living organism"; "a brand has its personality and personality attributes which are similar to human personality traits" (17, p. 303).

This position is shared by 0 . Kokoreva who states that a brand "is more than ... a graphic or verbal designation. Trademark protection may also be extended to distinguishable design and packaging, while a brand includes less distinguishable parts of the package, a recipe and its "know-how", slogans and symbolic elements associated with a brand" (8, p. 52).

Thus, the aspect concerning the protection of product composition, its "know-how" and manufacturing techniques distinguishes the trademark from the brand.

According to A.T.Volkov, the brand is understood to be a reputational asset which occupies a top-level position among the results of intellectual labor implemented in the market. Introducing "the pyramid of intangible assets", the author includes in its structure such components as human assets, assets embodied in corporate and innovation culture, organizational and managerial assets inherent in skills required for organizing and other functions, product technology assets (innovative assets), strategic assets, and reputational assets (3, p. 22).

The ratio of the notions representing the place of the brand among the individualization means is illustrated in Figure 2.

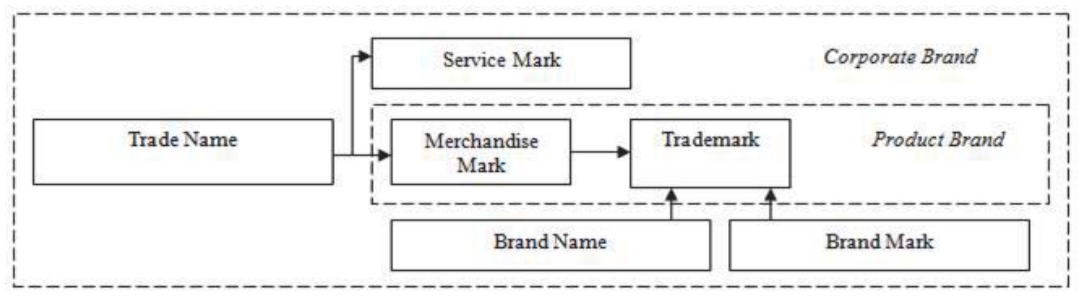

Figure 2. The ratio of the notions representing the place of the brand among the individualization means

From the perspective of an organization the role of brands is as follows:

- availability of brands provides additional cash flow and facilitates attracting new customers in case the brand is already familiar to them (guaranteed quality);

- brand awareness as well as perceived quality and brand associations residing in the minds of customers can increase a level of brand commitment;

- a brand allows you to charge a premium price and get extra profits; 
- a brand provides an opportunity to expand a product line, which is easier than to create a new brand;

- a brand reduces distributors' uncertainty, thus gaining an advantage and support when arranging goods in a sales outlet or carrying marketing activities;

- other brand assets develop competitive advantages and create barriers to competitors;

- a brand may reduce business risks and cut marketing costs;

- a brand provides a quick return on investment (product-development resources), and allows you to select an optimal brand strategy;

- a brand is an effective managing tool for a manufacturer when dealing with commercial agents. It is also a means for developing marketing and distribution channels as well as the image.

From the perspective of a consumer the role of brands is as follows:

- a brand means guaranteed quality. It serves as a prompt telling consumers which of competing products to choose and convincing them of product quality;

- a brand serves as a contract between organizations and a consumers which introduces mutually agreed commitments;

- a brand is a specific tool to inform consumers which they implement themselves;

- a brand allows consumers to save time and energy when choosing a specific product within the entire mass of commodities, which is much more effective in satisfying consumers' needs;

- a brand enables consumers to make an informed choice of high quality products and creates consumers' confidence in a manufacture;

- a brand releases consumers' resources and allows them to build up their own consumer capital, making them pay an appropriate price (a brand premium), etc.

\subsection{Components of the brand and their role in providing quality assurance.}

The product's value to a consumer is primarily determined by its product attribute component which is represented by a range of functional attributes that allow consumers to satisfy their needs. The product attribute component is also represented by several other characteristics such as aesthetic ones, as well as by those which make a product userfriendly.

It should be noted that product characteristics are not the only ones that determine consumer preferences. Such market supply components as service and information are no less important; for example, the product configuration based on individual customer requirements, goods delivery, provision of convenient payment options, warranty maintenance, extra services and other similar features which represent the content of such a market supply component as service. Both these features and product characteristics may influence purchase decisions.

In its turn, the information component of the product market supply also forms consumers' preferences. It includes a wide range of instruments for the product information support: from technical documentation and information on packing to advertising and information attributes of a brand.

Thus, it could be concluded that the role of the brand in formation of the information component of the product market supply as well as targeted consumer preferences is increasing if compared with the product attribute component and the service component.

Moreover, the phenomenon of the brand itself is a remarkable example of prevailing irrational influence of the information aspect of the market supply in the consumer preference structure.

This is due to the fact that the ratio of the components of the integrated product supply is determined not only by the product itself but also by its value image that resides in consumers' minds. Both rational and irrational factors influence the creation of such an image simultaneously. Therefore, it is possible that the information component of the product market supply represented by its brand name may be more important for a consumer than the product attribute component or the service component. In other words, consumer preferences for branded goods are determined by information about the product, and the information component of the product market supply represented by the brand becomes an effective tool for shaping consumer preferences.

This provides the basis for identifying the brand functions which meet the value criterion both from the consumers' perspective and the organization's perspective. They are quality assurance provision; customer commitment formation; development of a consumer-organization relationship system; added value formation.

Taking into account that traditions of ensuring consumer protection are not developed, and their legal mechanisms are insufficient, quality assurance serves as a principal function of the brand. Brand awareness and brand authenticity 
(lack of suspicion of unlawful use of a trademark) are effective means of influencing consumers, forming their confidence in purchasing quality goods, which are "protected" by a brand.

With due regard for differences between brands and trademarks it should be emphasized that a trademark is not a major factor which shapes consumers' opinions about a product and influences their purchase decision. A more important factor is the appellations of origin of branded products. Branded products can be manufactured in different regions of a country under the same trademark; therefore such products may have significant differences in quality.

This is due to the fact that:

- many manufacturers do not consider it necessary to register their trademark;

- Russian Legislation does not provide any powerful tools to fight against manufacture, distribution and sale of counterfeit and pirated goods. The market share of such goods remains very high. By some estimates, counterfeit foods make up about $35 \%$ of the total market (7);

- domestically manufactured goods are subject to counterfeiting activities more often than foreign ones. This fact proves the growing popularity of Russian trademarks, which do not have proper legal protection.

Moreover, Russian consumers use a wider range of preferred brand-name products to choose than foreign consumers. A foreign consumer has $2.0-2.5$ preferred brand-name products within each product group, while a Russian consumer has $2.5-5.0$ preferred brand-name products within the same product group $(13,15)$. It should be noted that more than two-thirds of Russian consumers' purchases are goods which are purchased on an occasional basis.

This circumstance affects terms and cost of creating new brands. For example, in the USA bringing a new brand to market takes on the average 24 months and costs $\$ 5$ million. A great number of brands (about 75,000 brands) are brought to the U.S. market annually. According to some experts, in order to saturate the Russian market it is necessary to bring out at least 500 new trademarks a year $(14$, p. 311), which may strengthen a functional effect of the brand on consumers in terms of quality assurance.

\subsection{The role of the brand in formation of customer commitment and added value.}

From the perspective of a consumer, high brand commitment means that regular availability of branded goods is very important for them (6). From the perspective of an organization, brand commitment makes it possible to reduce market risks under conditions of growing competition for consumers. It can attract distributors who are interested in selling highdemand goods. Thus, high brand commitment helps organizations build a sound system of relationships both with distributors (9), and consumers (18).

Brand commitment is one the most examined functions of a brand. O.A Tretiak emphasizes that brand commitment is very important because it can impact effectiveness of organization's marketing activities. He identifies several levels of brand commitment and provides a typology of customers. There are such customer types as: "a wanderer focused on price" (indifference to a brand); "someone accustomed a brand" (lack of complaints regarding a brand); "a brand follower who was refocused" (brand satisfaction); "a brand's friend" (brand preference); "a brand's follower" (brand commitment) (17, p. 307-309).

Regardless of the level, nature or type of brand commitment, the very fact of its formation under brands' influence proves their functional mission. Being a brand attribute, brand commitment is very important for creating added value.

In our opinion, the latter can integrate other brand attributes if to take into account the initial criterion of their identification (from the standpoint of consumers and organizations, it is value).

Added value formation was examined in detail by L. de Chernatony and M. McDonald. According to them, added value is the difference between a brand and a generic product (a product that does not have a trademark) when analyzing the ratio of price differentiation and product differentiation / image differentiation (19, p. 14). The nature of these values is primarily emotional. They are the results of implementing effective marketing strategies focused on establishing certain attitudes in the consumers' minds to a brand in a particular market. In generic products markets they are perceived by consumers nearly identically as they occupy the same position and are interchangeable. The probability that a consumer will prefer a substitute product decreases, when a brand with features which are positive to consumers comes to market. These features create added value.

As L. de Chernatony and M. McDonald state, consumer choice depends on the product surrounding (the product aura), which can account for as much as 80 percent of added value and impact of a product or services, while these only account for about 20 percent of costs $(19$, p. 7). Considering the brand as an organization marketing asset, the authors explain its role in the context of building relationships with consumers. They note that such relationships are personified by means of a company name, a brand name or a product itself.

According to David A. Aaker and E. Joachimsthaler, a branded product's added value is formed by means of such 
elements as an image of an organization, brand uniqueness, symbolic elements, brand-consumers relationships, selfexpressive and emotional benefits, usage image, a country of origin (2, p. 67).

We believe that the role of a brand as a source of added value should be considered from the standpoint of utility theory. In this case it should be applicable both to a product and an organization which supplies this product to a consumer.

It is clear therefore that when making purchases, a customers' purchase is not a set of functional attributes of the product, but a specific set of benefits provided by this product.

From this point of view the product is not merely a target. It is a means to satisfy specific consumers' needs and meet their demands. In the context of market saturation, tangible characteristics of the product determine its use value not so much as its intangible characteristics; for, analogous products can have the same tangible characteristics, while intangible characteristics are formed by means of individualization.

Moreover, the multiplicity and diversity of market actors (organizations and enterprises), which provide consumers with products they need, give an opportunity to choose among market actors; therefore, intangible characteristics of the value of an organization to a consumer (e.g. quality of service, optional services, quality assurance, merchandise return, etc.) also vary.

The stated circumstances allow us to determine formation of the product (organization) added value as a brand's basic function and schematically present their correlation for demonstrating both tangible and intangible values of a product's characteristics and intangible characteristics of an organization (Figure 3).

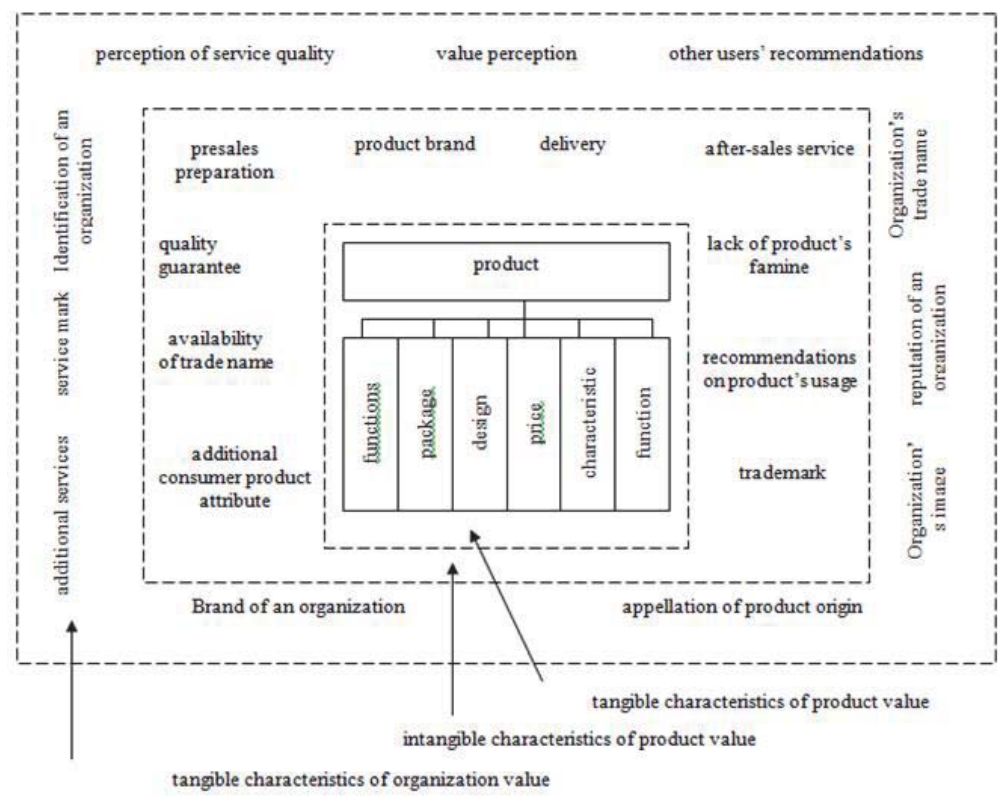

Figure 3. Items of value added formation with a glance to individualization means

\subsection{Typology of brands.}

The final aspect of our study, which reveals brands' roles and functions in individualization of products and organizations, is associated with typology of brands.

Approaches to identification of brands' types given by different authors vary widely. R Langmaid and W. Gordon classify them on the basis of their usage in advertising by means of pointing brands' types on the graduation line of nine categories. At the top of the line there are brands connected with ordinary associations (verbal, acoustic, visual); in the middle part there are branding techniques, symbols, analogues, metaphors, tone of voice; at the bottom part of the line (the most difficult one) there is a structural branding (25, pp.15-46).

Recognizing the original nature of this approach to typology of branding, we consider it is simplified because reflection of only promotional aspects of brands' usage diminishes importance of other marketing-mix elements usage, which are of no less importance for branding creation. 
L. de Chernatony and M. McDonald justify their typology brands, explaining it as a sign of ownership, a differentiating device, a functional device, a symbolic device, a risk reducer, a shorthand device, a legal device, a strategic device (19, pp. 47-56).

In this approach to typology of brands, in our opinion, we can see a brightly stated "mechanical" aspect, which reduces brands to a "device" or a "mechanism" without depicting their role in the value creation process.

M. Goodyear offers his variant of brands' typology, describing them in consumerism continuum terms used to characterize a dialogue between marketers and consumers. The author arranges brands' characteristics due to their evolution from a generic brand, a brand as a reference, a company's "icon" up to a brand as a policy when the latter is considered as a quality indicator (23, pp.10-22).

This approach to the brands' typology seems to be more successful than the above discussed approaches. However, in our opinion, it gives a too laconic statement of a brands' role, without considering the system of their relationship with other aspects of an organization marketing activities and other types of marketing tools.

As a consequence, based on the approach of consumerism continuum terms which are used for characterizing a dialogue between marketers and consumers, as well as on the basis of other defined approaches to the typology of brands, it is difficult to define their role-based functions, which could become the key ones for any organization involved in building branding as a system.

In our study, branding is treated as a systematic, task-oriented marketing activity of an organization in the field of creation, promotion, enhancement and development of brand names, which is centered on development of customers' commitment and loyalty to a product (organization), which act as a factor of brand equity formation and are subjected to managerial influence.

On the basis of the given information, we believe it is possible to propose a typology of brands, while taking into account a degree of their influence on a creation of added value, and divide them into generic, expected, enhanced, potential, etc.:

- generic brands satisfy consumers' basic needs; are easily copied by competitors, and therefore brands of this level should have added value of the expected level;

- expected brands satisfy consumers' minimum target requirements stated during purchasing (price, functional characteristics of the product, etc.); increasing frequency of product purchases needs in increasing of resources for creating added value associated with quality service improvement;

- enhanced brands satisfy afunctional consumers' requirements (psychological, status, emotional, etc.); functional needs, which are clearly defined in the mind of a consumer who explicitly identifies the wanted product or organization by its credibility in the market;

- potential brands are oriented to "strategic popularity" of branded products among consumers; an organization's long-term positive image; shaping of the segment of regular customers who are confident in product and service quality; a brand's added value is formed by creating sustainable relationships with consumers.

Summing up the information, we emphasize that active development of a brand's theoretical concepts and emergence of various approaches to its nature definition indicate the necessity to understand branding as a market phenomenon, acknowledge strengthening of its influence on a consumer's preferences shaping, market development and results of its entities operation.

The brand is formed as a result of purposeful activities in the sphere of brand's promotion in the market in such a way that a high level of consumers' loyalty can be achieved and, consequently, economic efficiency of the organization and its long-term market stability can be established.

We come to the conclusion that due to its goal-directedness branding has a systemic nature, is liable to managerial influence and should be viewed as an integral process of brands' creation, support and development.

\section{Conclusion}

The variety of organizations creates for consumers an alternative choice when they buy products, and therefore organizations should have a personality which could help customers to identify them. Means of individualization help to create distinguishing features of organizations. These means can be applied not only to an organization. Equally important they are for identifying products, work and services due to the lack of an explicit product differentiation in the consumer market.

In conformity with the current Russian legislation means of individualization are: a company name, a trademark, a 
service mark, appellation of products origin. Means of individualization, with the exception of brands and trademarks, are regarded as an element of intellectual property. The authors stated interrelation of the concepts, which shows where the brand fits in the means of individualization; specified its role; pointed out and emphasized the basic functions; proposed a typology of brands, based on the degree of their influence on the added value formation. Further studies will be carried out in the sphere of branding perspective development, which is defined as a systemic activity of an organization centered on creation, promotion, enhancement and development of trade marks.

\section{References}

Aaker, D.A. (2003). Building of Strong Brands. Moscow: Grebennikov's Publishing House.

Aaker, D.A, Yohimshtayler, E. (2003). Brand Leadership: a New Concept of Branding. Moscow: Grebennikov's Publishing House.

Volkov, A.T (2006). Strategic Brand Management and an Organization's Capitalization. Marketing, (89), 19-29.

Civil Code of the Russian Federation. Parts one and two (with catchwords index). (1997). Moscow: INFRA-M-NORMA.

Eliseev, A.N, Shulga, I.E (2005). Institutional Analysis of Intellectual Property. Moscow: INFRA-M.

Klimenko O.I, Klimenko, A.A, Oberemko, V.V (2013). Improving of Economic Tools for Using Competitiveness Generation Factors of a Trade Organization. Belgorod: Publishing House BUCEL.

Klimenko, A.A, Polovinchuk, D.J. (2014). Public Catering Establishment's Brand Influence on Customers' Satisfaction and Loyalty in the Context of the Theory of "Customer's Value". Bulletin of Belgorod University of Cooperation, Economics and Law, 3 (51), 291297.

Kokoreva, O. (2000). Licensing of Trademarks and Brands. Financial business, 11-12, 46-54.

Kotler, F, Pfoertch, W. (2007). B2B Brand Management. Moscow: Vershina.

Kotler, P., Keller, K.L (2009). Marketing Management. St. Petersburg: St. Petersburg.

International Classification of Goods and Services for the Registration of Marks. (1996). Moscow: Progress

Menard, C., Valtseskini, I. (1999). Creation and Protection of Collective Marks. Problems of Economics, 3, 75-82.

Mozgovaya, J.A., Semenchenko, E..N (2014). The Concept of Brand and its Impact on the Innovative Activity of the Enterprise. Bulletin of Belgorod University of Cooperation, Economics and Law, 1 (49), 321-326.

Pankrukhin, A.P. Marketing. (2006). Moscow: Omega-L.

Rozdolskaya, I.V. (2014). Incorporation of Creative Elements into the Management Processes in the Presence of Interactive New Marketing Environment. Bulletin of Belgorod University of Cooperation, Economics and Law, 1 (49), 46-54.

Rumyantseva, E.E. (2006). New Economic Encyclopedia. Moscow: INFRA-M.

Tretiak, O.A. (2005). Marketing: New Directions of a Management Model. Moscow: INFRA-M.

Hill, N., Brierley, J., MacDougall, R. (2010). How to Measure Customers' Satisfaction. Moscow: INFRA-M.

Chernatony, L., McDonald, M. (2006). Branding. How to create a powerful brand. Moscow: UNITY-DANA.

Aaker, D.A. (2004). Brand Portfolio Strategy. New York: The Free Press.

Bedbery, S. A. (2002). The New Brand World. New York: Viking Penguin.

Clifton, R and Simmons, J. (2003). Brands and Branding. London: Profile Books.

Goodyear, M. (1996). Divided by a Common Language. Journal of Market Research Society, 38 (2), 10-22.

Keller, K.L. (2003). Strategic Brand-Management. Upper Saddle River, N: Prentice-Hall.

Langmaid, R. and Gordon, W. (1998). A great Ad-pity They Can't Remember the brand-true or false: B3lst MRS Conference Proceedings. London: MRS, pp.15-46.

Reicheld, F., Teal, T. (2003). The Loyalty Effects. Boston. MA: Harvard Business School Press. 